\title{
Octavio Paz: La Gimnasia Poético-Crítica
}

No puede haber dos libros más aparentemente dispares que éstos de Octavio Paz. ${ }^{1}$ Antes de ser impresos en castellano, el primeroapareció en traducción inglesa, el otro en traducción francesa; es decir que sus públicos iniciales distaban bastante de los lectores hispánicos que suelen ser los primeros en recibir sus palabras. La verdad es que Latinoamérica está ya en condiciones de prestaral mundo occidental uno de los escritores contemporáneos más originales, situación muy contraria a lo que ha sido el caso en muchos años. $\mathrm{Y}$ estos dos libros se reparten el mundo entre sí: Los bijos del limo mira hacia Occidente, su poesía, su política, su posible futuro; El mono gramático se planta con su mismo título en lo más sagrado de la religión hindú, en cuyos mitos los avatares de los dioses se incorporan otra vez en vida. Este libro se desarrolla como un contrapunto entre la prosa y las artes visuales, arquitectura, pintura y fotografía; aquél explora el poder de la palabra, y la enorme soledad moderna de nuestro hemisferio. El uno resulta ser algo como un largo poema concreto; el otro una critica embelesadora.

Sin embargo, resulta axiomático decir que ambos libros son hojas en el gran libro que es la obra de Octavio Paz. Nacieron bajo presiones análogas-son obras de circunstancias, como lo han sido tantas y tan buenas en el pasado. Ya no son los aristócratas mecenas los que piden elegías o elogios para conmemorar a sus familias a veces brillantes, a veces medio cretinas. Ahora es una editorial como Skira que pide una contribución a una serie, o la universidad de Harvard que quiere enriquecer su microcosmo académico con la presencia de los pensadores y creadores más originales. Se obliga al poeta a medir no solamente su público sino su medium: conferencia hablada o exploración de los confines de este no-man's-land entre poesía y arte visual. Siendo su contenido funcional, la forma de ambas obras será (como siempre es el caso, dicho sea de paso) la sustancia misma bajo las exigencias de esta función.

Esto en el nivel más superficial. Pero hay una correspondencia más profunda entre estos libros, y es aquí donde vislumbramos este substrato particular a cada creador que es para él lo que la chispa divina en el espíritu del místico. La dialéctica fundamental que inspira tanto Los bijos del limo como El mono gramático es la eterna lucha entre el lenguaje y la comunicación; entre el lenguaje, representación discontinua de signos arbitrarios pero asociativos, y la comunicación, sistema continuo de relaciones entre el ser humano y lo que le rodea, sea otros seres, el mundo natural o el ecosistema en general. En dos "circunstancias"' muy distintas Paz responde con un

${ }^{1}$ Los bijos del limo (Seix Barral, 1974) y El mono gramático (Seix Barral, 1974). 
libro que funciona como agente de mediación en esta dialéctica conflictiva. Acérquese el estímulo para la creación del texto a su sentido crítico (Los bijos del limo) o a su inspiración creadora ( $E l$ mono gramático), la respuesta instintiva de $\mathrm{Paz}$ representa una búsqueda del equilibrio, y su libro emerge nítido, inimitable, guiándonos a una visión más íntegra del ser diferenciado que demasiado a menudo ha hecho de sí mismo el hombre moderno.

Si el acto de escribir en el caso de Paz se puede llamar mediación, no nos sorprenderá que la clave a ambas obras sea la analogía, explorada en múltiples niveles y sentidos. El mono gramático muestra implícitamente la relación análoga entre poesía y pintura, o sea dos de las manifestaciones de esta oscilación del hombre entre el deseo y el pensamiento. Paisajes verdaderos, visiones imaginarias, imágenes religiosas, pinturas abstractas alternan con la prosa de estas páginas. Al lector le toca percibir la relación entre la sucesión linear de signos impresos en la página y la impresión sincrónica que recibe de las imágenes visuales. Como eco de los motivos que reaparecen en la prosa-camino, árbol, signo, escritura, unión sexual-el palacio de Galta vuelve varias veces como un bajo continuo en la música barroca: el palacio arruinado, capturado por la máquina fotográfica en distintas luces, con distintos enfoques, disimulado por trucos técnicos del fotógrafo, siempre diferente en el momento pero siempre el mismo en el tiempo.

El viaje físico a Galta fija otro nivel analógico, puesto que el poeta funde en el tópico "viaje", todos los otros posibles viajes del hombre-el peregrinaje, el viaje místico del santo o del sadhu, el viaje amoroso con la amada que en el Budismo tántrico cierra este círculo de viaje-búsqueda. Para el tantra el cuerpo es una geografía, y los sitios sagrados de éste son los sitios sagrados, meta del peregrino religioso. En su poema Blanco Paz nos invitaba a que nos abriéramos a una lectura más que lineal y cronológica, dando a la columna central (espina dorsal) del texto alas y aperturas que pedian una relación instantánea y múltiple entre lector y poema. En El mono gramático las láminas interrumpen el texto pero al mismo tiempo son el texto ampliado que percibimos, rompiendo el vínculo que nos aprisiona a la lógica de la palabra y al orden sintáctico. El libro está escrito en prosa, lo cual nos condiciona todavía más a esperar un argumento lógico y cronológico. En cambio la multivocidad de la palabra clave "camino" y el contrapunto de rupturas del orden lineal de la palabra que producen las láminas, nos confrontan con esta ambigüedad poética y revolucionaria en donde se rompen fatalmente nuestras ideas preconcebidas de una relación estable entre significado y significante. Nuestra seguridad linguiística se quiebra aun más cuando desaparece la discursividad de la prosa, y un mundo de relaciones infinitas e inimaginadas se abre como un abismo insondable a nuestros pies.

De igual modo el mono grarnático rompió las fronteras entre el hombre y sus posibilidades físicas. Hanuman es un personaje venerado por toda la India como símbolo de devoción a la deidad. Era un mono racional, más, era "the ninth author of grammar," o, dicho de otro modo, era un hombre de mente excepcional en un cuerpo simiesco. En la epopeya hindú Ramayana sirve como el agente para la salvación de Sita, esposa del dios Rama, la cual fue capturada por Ravana, rey de los diablos. Ravana la tenía cautiva en la ciudad infernal de Lanka, situada en lo que hoy es Ceilán, pero con su fuerza física Hanuman cruzó de un salto el estrecho, y atacó a Lanka con su ejército de monos. Quemó la ciudad y llenó el estrecho en preparación para el ataque de Rama. Para curar a los muchos heridos entre las tropas del dios-héroe éste fue volando al Himalaya y trajo de allí una montaña donde crecía una hierba medicinal de extraordinaria potencia. Como resultado de tal devoción Rama recuperó a Sita, y el reino de la 
armonía se reestableció en la India. El templo de Galta es uno de los sitios dedicados a la devoción de Hanuman; espacio y tiempo coinciden en el festival religioso que el poeta encuentra al fin de su camino. Los legendarios personajes, con las escenas más dramáticas de la epopeya, sirven como uno de los leit-motifs del libro, como también el tema erótico que se manifiesta en alguna que otra cita de los textos sagrados, y en los pasajes que celebran la unión con la amada, apareciendo repetidas veces en las láminas, orientales y occidentales, antiguas y modernas.

El libro tiene veintinueve momentos, en donde un tiempo presente en Churchill College, Cambridge, alterna con un recuerdo revivido del camino hacia Galta durante la época de un peregrinaje. Alterna también con le libro sagrado de Rama, con el "libro de la naturaleza," con una exploración del lenguaje, y con un poema de amor. Todos estos momentos son búsquedas, pero la búsqueda es siempre la misma. El poeta descifra signosla naturaleza, el mito, la pasión, una geografía cósmica/corporal-que le conducen hacia el momento de convergencia de todos los puntos, donde aparición y desaparición son lo mismo, donde el hombre se reconcilia con el mundo y consigo mismo mediante el poema (el nombrar es el acto simbólico de reencontrarse en el lenguaje que es el mundo) y en la comunión con el Otro (amar, re-unirse, hacerse momentáneamente Uno).

Hanuman desafió las leyes naturales y rompió las limitaciones de su fisiología. En el viaje sagrado que es la vida del hombre, la mística de la poesía (de todas las artes) y de la pasión, forja rupturas en la sucesión cronológica del tiempo y en el orden discursivo del lenguaje. Los bijos del limo presenta otra paradoja: tal como Hanuman se sometió a Rama, el poeta limita sus poderes para ponerlos al servicio de la crítica, hombre/mono, poeta/crítica libremente restringido en una causa más total. Paz nos advierte sin ambargo que esta discusión de la poesía moderna "del romanticismo a la vanguardia"' se define para él en términos de una auto-exploración, como el viaje a Galta sirve como metáfora para el viaje hacia el misterioso centro de su propio ser de hombre/poeta. Se acerca a las corrientes de la poesia europea de los últimos ciento y pico de años con la comprensión y el poder de síntesis que siguen asombrando y humillando a los lectores de Octavio Paz (y en este caso oyentes, puesto que se trataba originalmente de los Charles Eliot Norton Lectures). Como el Hanuman del mito, $\mathrm{Paz}$ nos conquista con sus saltos inverosímiles, llevándonos de la metafísica tradicional, mediante la ruptura poética de los románticos, a la metafísica negativa de un mundo sin Dios, la metafísica dudosa del arte contemporánea. Penetra el fenómeno del "modernism" anglo-sajón en sus diversas facetas e influencias, y se muestra uno de los muy pocos críticos capaces de abarcar la literatura del siglo veinte en su totalidad. Por una vez encontramos la poesía castellana (de la Península y de Latinoamérica) en su sitio adecuado - dentro de un contexto occidental. Y también como Hanuman sus exploraciones contienen un elemento terapéutico. Se confronta con las implicaciones políticas de la "tradición de la ruptura," analizando el verdadero alcance de una revolución de la palabra, sometiendo el esteticismo a un escrutinio severo pero curativo. Muestra la interdependencia de artista y sociedad, y al examinar las responsabilidades de aquél nos recuerda las nuestras; cruza el abismo (¿llena el estrecho?) entre la actividad política - en su sentido más puro - y la actividad mental, creadora.

El capítulo clave del libro es el cuarto, "Analogía e ironía" - ¿cómo podría no serlo? Aquí explora cómo el Romanticismo con sus dos vertientes (una oficial, transparente, la otra subterránea y satánica) cambió en su raíz nuestra visión del arte. Muestra cómo la analogía, siempre presente aunque no siempre visible, vuelve a ofrecerse a un mundo que, como el nuestro, 
buscaba soluciones para poder vivir. Pero para los que han perdido el sentido de lo absoluto, la analogía gira en torno a un centro vacío-la ironía. Paz explora esta tendencia a la polarización en otras manifestaciones también: Catolicismo y Protestantismo, por ejemplo, prosodia silábica y prosodia acentual, la Nada y la Obra de Mallarmé.

Cuando las dialécticas se resuelven en silencio para el poeta, el crítico da otro salto. Penetra a lo más íntimo del Modernismo en unas pocas páginas cuya perceptividad compensa los muchos tomos vacíos escritos sobre este fenómeno, no tan fenomenal, al fin y al cabo, pero por esto mismo más actual. El capítulo final es un tour de force de acrobacia mental. Titulado "El círculo se cierra,"' describe en efecto una sucesión de pequeños círculos, cada uno un acto de síntesis de elementos aparentemente opuestos: la poesía y la política; afirmación erótica y negación irónica; cambio y stasis; arte y vida. Estas oposiciones se demuestran y se resuelven en las rupturas cada vez más deslumbrantes del siglo veinte, movimientos poéticos y revolucionarios que se contradicen y se anulan mientras acelera el ritmo del progreso. Al fin todo alcanza una velocidad que también se anula porque viene a igualar la inmovilidad del mito. Hoy en día el progreso y el cambio se han desdicho; nos encontramos en un tiempo fuera del tiempo, el tiempo ucrónico antes de que todo vuelva a empezar. Paz nos deja en este momento dinámico cuando un orden se muere y otro se prepara a nacer.

El libro termina con una crítica no de la poesía sino del subjetivismo del poeta. Consciente de la inestabilidad del lenguaje que los poetas "revolucionarios" desde Mallarmé y Lautréamont nos han hecho sentir en el centro de nuestro ser, la poesía de hoy, lo mismo que la filosofía y la sicología, reniega del concepto mismo de un "yo" con un centro permanente y definible. Volvemos a la contemplación del texto, del misterio del lenguaje que quiebra nuestra seguridad cartesiana, pero que contiene la magia creadora de hacer ser. En una novela que es al mismo tiempo un acontecimiento histórico y un testimonio atemporal, E. M. Forster nos lo ha dicho también. "'Only connect," dice en Howard's End, y la obra de Paz en ambas manifestaciones consideradas aquí, como en todos sus otros momentos de aparición, es una cadena interminable de "conexiones." Paz exige un lector-Hanuman con todos sus sentidos alertos para cumplir el acto recíproco que es, según su visión, la creación poética/crítica, la invención de la palabra. 